\title{
Application of Contextual Teaching and Learning Approach on Statistics Material Against Student Results
}

\author{
Aaltje Pangemanan ${ }^{1}$ \\ ${ }^{1}$ Mathematic Education Study Program, Mathematics and Science Faculty, Manado State University, North \\ Sulawesi, Indonesia \\ Correspondence: Aaltje Pangemanan, Mathematic Education Study Program, Mathematics and Science Faculty, \\ Manado State University, North Sulawesi, Indonesia. E-mail: aaltjep@yahoo.com
}

Received: September 9, 2019

Accepted: October 17, $2019 \quad$ Online Published: February 27, 2020

doi:10.5539/ies.v13n4p1

URL: https://doi.org/10.5539/ies.v13n4p1

\begin{abstract}
Based on empirical data, student learning outcomes on statistical material are not in accordance with the expectations of teachers so it is necessary to apply the Contextual Teaching and Learning (CTL) approach. A CTL implementation can help students to understand concepts and skilled resolve issues. The research purpose is to see whether the students learning outcomes on statistics materials that are taught using the CLT approach are better than conventional approaches. The methods used are experimental studies and the data will be obtained from the pre-test and post-test learning outcomes. The population are the entire class IX student while samples taken by random sampling techniques, two classes, namely as an experimental class and control. Research design is a Non-equivalent Control Group Design. Based on the results with two average difference tests on T-Test statistics were obtained that student learning outcomes in experimental class is higher than the controls. This means learning by applying the CTL approach can improve learning outcomes and the benefits for mathematics teachers gained insight into the CTL learning process.
\end{abstract}

Keywords: contextual teaching and learning, conventional, statistics, learning outcomes

\section{Introduction}

A formal learning process is essentially an activity that aims to allow students to achieve the minimum submission criteria or be able to have better learning outcomes. Better mathematics learning results are the goal of learning and to get the results need a good learning process. One benchmarks of the process is that students must be active in the learning process and a good learning process is teachers able to motivate students and became happy to learn mathematics. Based on the initial observation of the learning process that the author did at SMP N 6 Tondano, the delivery of material to students often with conventional expository and rarely replace with the other learning approach, whereas Mardianto and Wijaya (2016) said that on learning with the CTL make the students answers became more varied than conventional learning. The learning process that uses the CTL approach to statistical materials can have a good impact on student learning outcomes, as students can quickly master the material because learning and resolving problems are always related practically. According to Sudjana (2003), learning is a process characterized by the change in a person. Skiner cited by Fathur (2007), defines learning as a process of adaptation or behavioral adjustments that take place progressively or learn as a change of behavior.

The change in behavior achieved as a result of such learning through the process of strengthening the new behavior that appears is known as operant conditioning. Learning mathematics, in it there is the Statistics School material which is a science that learns about how to find, collect, process and interpret data, this is a way to get the truth. According to Ruseffendi (1993) searching for truth in mathematics usually begins with inductive means, wherein in mathematics a generalization, trait, theory or evidence is not acceptable to its truthfulness before it can be proved in deductive, thus the mathematical essence relates to the definitions and the relationships set according to the logical rules in order to understand the meaning of the ideas contained in the symbols, as well as to understand the relationship of those ideas. Suriasumantri (2010) said that, mathematics is a language that symbolizes a series of meanings from the statements we want to convey. The symbols of mathematics are artificial that have only meaning after a meaning is given to the emblem. So mathematics determines more mental activity than physical activity, instructing skills and thinking skills are needed in learning especially when resolving statistical issues to be interpreted and this will be proved in student learning outcomes. Sudjana (2003) states that the outcome of 
learning is a behavioral change that arises for example from not know to know. The change in behaviour that occurs in the learning process is an experience or practice done intentionally and consciously not by chance. A successful learning cannot be reviewed from the learning process itself and the learning outcomes achieved by the students. As concluded by Kurniati et al. (2015), CTL has an effect on the ability to think critically mathematics. As a science, statistics are applied mathematics that the learning process is much related to concrete examples that are directly related to real life so the way teachers teach will be one of the determinants in how students think.

CTL was developed by The Washington State Concortium for Contextual Teaching and Learning, which involved 11 colleges, 20 schools and institutions engaged in education in the United States. One of its activities is to train and and provide opportunities for teachers from six provinces in Indonesia to learn contextual approach in the United States, through the Directorate of National Education Ministry. Johnson (2011) suggests that the connection that leads to meaning is a process of learning using the CTL approach. As the results of Mauliana et al. (2018) research that learning tools with CTL can be used on the rectangular topic to establish mathematical connections. In addition to rectangular topics, researchers can help students associate statistical material with real-life contexts.

CTL in Elaine B. Johnson's book (2011) is an approach to the teaching and learning process in order act to look for productivity of learning with the concept that will help teachers connect the subjects and actual life problems and also to encourage the student to correlate them. The CTL approach involves seven main components of effective learning (C-STAR, 2001), that is: Constructivism, Questioning, Inquiry, Learning Community, Reflection, Modeling and Authentic Assesment. The CTL approach in this context students need to understand what the meaning of learning, the benefits of learning, and how to achieve it. Here students will find that what is learned is useful for the later life, so it will make students positioned as themselves who need a provision that is useful for later life and students will try to reach it.

This study presents the correlation between the materials that students learn with the context of where it is used, as well as in relation to the concept of how students learn. It is different from conventional learning that teachers often use and even very widely used by teachers. This conventional learning is teacher-centered learning, where all learning activities are conducted by teachers, teachers play a key role in determining the content and learning processes, including assessing student learning progress. According to Pattimukay (2009) the conventional learning is learning process that generally performed in schools, which is learning that begins with material exposure, then given examples of the questions and last evaluation through the question exercise. Conventional learning generally has certain specificity, such as more memorization than understanding. So in this case researchers get a formulation that, student learning results taught using the CTL approach will be better than conventional on the statistical material and beneficial to students because they can solve mathematical problems contextually which are evident in their daily lives, as well as for mathematics teachers who gain insights such as examples of the CTL approach steps in managing and designing the learning process.

\section{Method}

\subsection{Subject}

1) The population is every students grade IX of Public Middle School 6 Tondano.

2) The sample of this study would be taken with random sampling technique, which is taken from 2 classes: class 1 as the experiment class and class 2 as control class

3) Research time adjusted to the schedule of subjects in the school.

\subsection{Variable Operational Definitions}

1) The independent variables on this research are:

a) The treatment variables include applying the CTL approach to the student class experimental.

b) To control the conduct of experimental research: Learning time is relatively the same; the material is the same and the teacher alike.

2) The dependent variable is student learning outcomes in Statistics material. The learning outcomes are obtained from the post-test scores in the experimental class and the control class.

\subsection{Research Design}

This research is a quasi-experimental study that is adjusted to the CTL and conventional steps and learning tools such as: lesson plans and learning outcomes measurement tools. The design of this study is Non-equivalent Control Group Design where there are two classes in this design, namely the experimental class and the control 
class.

Table 1. Non-equivalent control group design

\begin{tabular}{cccc}
\hline Group & Pre-test & Treatment & Pos-test \\
\hline Experiment & $\mathrm{T} 1$ & $\mathrm{X}$ & $\mathrm{T} 2$ \\
Control & $\mathrm{T} 1$ & & $\mathrm{~T} 2$ \\
\hline
\end{tabular}

Note. T1: Pre-test score, T2: Post-test score, X: Implementation of Learning by using the Contextual Teaching and Learning Approach (Sugiyono, 2010).

\subsection{Data Collection}

Data collection was done by provide a final test (post-test) in the experimental class and the control class.

\subsection{Research Instrument}

The instrument of this study is a test of learning results of mathematics made by teachers in essays. Before a learning instrument is used, the content validity test first performed, which means that measuring instrument is considered valid when it can measure specific objectives that align with the material or content provided based on the existing curriculum. The validity used is the validity of the content, which is to ask the expert team opinion about the tests that are feasible to use. Data collection techniques are by giving preliminary tests (pre-test) and final tests (post-test).

\subsection{Research Procedure}

There are 7 main components of the CTL approach that need to be considered according to the explanation above but in this study researcher modified it by added components (develop thought) because of due attention to the students needs, so here 8 components are as follows:

1) Develop thought, is a preliminary activity where teachers embed the thinking of students learn more meaningful by way of self-work, find themselves, and self-construct new knowledge and skills.

2) Inquiry. Teacher begins the lesson by asking a question where the students are invited to actively participate in solving the problems presented. Examples: Understanding statistical material in particular the material presents and interprets the data in which there are sub-points of the mean, median, and mode of data. The steps in the CTL learning process are as follows:

a. Teachers bring students into a commonly perceived context:

a) Teachers invite group students.

b) Each student is assigned an assignment to each group such as ; group 1 makes a task about collecting sandals numbers from group friends, group 2 makes a task about collecting a number of friends houses, and group 3 makes a task about their friends age, etc.

b. In subsequent activities,

a) To calculate the average result of the questions above, the teacher can assign the existing student to calculate together the amount of data by summing up all the data each group has based on the observation in the class. Then the existing values are divided by the number of students who are asked for the data. Students must understand that mathematics is closely related to daily life.

b) Students can model the question into mathematical models with the mathematical emblem for the mean calculations.

$$
\text { Average }(\bar{x})=\frac{\text { Sum all values }}{\text { Number of values }}=\frac{x_{1}+x_{2}+\ldots+x_{n}}{n}=\frac{\sum_{i=1}^{n} x_{i}}{n}
$$

Students then analyze which values often appear in previous data collection, and also look for the middle value of the data.

c) The teacher invites students to conclude through the understanding that has been found during the completion of the problem.

3) Questioning. By asking teachers to explore the most important part in implementing the study, which is digging information, coordinating what is already known, at this stage the teacher constantly encourages, 
guides and assesses the students thinking skills in ask questions relating to the material, for example "What is the purpose of learning mode?".

4) Constructivism. Teachers can build students understanding of the material relating to daily life, such as the average student who comes to school by not taking a car, this is where students understanding is more developed.

5) Learning Community. This stage teachers give students the opportunity to work together with friends to help each other.

6) Reflection. This reflection is done at the end of learning, its realization as the teacher gives a direct statement about the material students learn and records the things that are a new subject or idea that the student encountered during the lesson.

7) Modeling. This is where teachers require students to be able to see how students relate this lesson to various disciplines, teachers expecting students can think that mathematics can be attributed to other fields of science because of mathematics as queen and servant for other sciences.

8) Authentic Assessment. This assessment is done after completion of the learning process where the students complete the worksheet. The description above can be summarized as Table 2 below.

Table 2. Summary of the CTL implementation steps for statistical learning

\begin{tabular}{|c|c|c|}
\hline Stage of Activity & Teacher Activities & \multirow{2}{*}{$\begin{array}{l}\text { Student Activities } \\
\text { Observing and preparing books, writing } \\
\text { stationery needed in the learning } \\
\text { process, students are actively involved }\end{array}$} \\
\hline $\begin{array}{l}\text { Stage I } \\
\text { Introduction/Develop thought }\end{array}$ & $\begin{array}{l}\text { Teachers conveys basic competencies, learning } \\
\text { indicators and leaning outcomes, learning objectives, } \\
\text { subject matter, and motivating students to be actively } \\
\text { engaged in learning activities }\end{array}$ & \\
\hline \multirow{5}{*}{$\begin{array}{l}\text { Stage II } \\
\text { Inquiry }\end{array}$} & $\begin{array}{l}\text { - Teachers provide opportunities for students to } \\
\text { do observations or study individually subject }\end{array}$ & $\begin{array}{l}\text { - Observe (study the lesson } \\
\text { material) independently }\end{array}$ \\
\hline & & Analyzing the subject matter \\
\hline & Discussing together with students for problems & independently, \\
\hline & found by students & Reveal questions/problems \\
\hline & $\begin{array}{l}\text { Teachers guide students or some students for } \\
\text { problems found by them }\end{array}$ & $\begin{array}{l}\text { Ask for guidance on teachers or } \\
\text { friends }\end{array}$ \\
\hline $\begin{array}{l}\text { Stage III - IV } \\
\text { - } \quad \text { Questioning, guide the group to } \\
\text { work and learn } \\
\text { - } \quad \text { Asking } \\
\text { - } \quad \text { Constructivist }\end{array}$ & $\begin{array}{l}\text { Teachers ask, and guide groups who have } \\
\text { difficulty resolving problems } \\
\text { Teachers build understanding of students in } \\
\text { relation to daily life }\end{array}$ & $\begin{array}{l}\text { The group asks questions for the } \\
\text { problems experienced and creates } \\
\text { a report of the group's work. } \\
\text { Students can understand examples } \\
\text { relating to real life. }\end{array}$ \\
\hline $\begin{array}{l}\text { Stage V } \\
\text { Learning Community: building } \\
\text { togetherness; Analyze and evaluate the } \\
\text { problem resolution process in a } \\
\text { worksheet }\end{array}$ & $\begin{array}{l}\text { Teachers ask each member of the groups to gladly } \\
\text { help a troubled friend, conclude or evaluate the } \\
\text { group's work }\end{array}$ & $\begin{array}{l}\text { Each member of the group who is having } \\
\text { a bold problem asks a friend, concludes, } \\
\text { evaluates the outcome of their work }\end{array}$ \\
\hline $\begin{array}{l}\text { Stage VI } \\
-\quad \text { Reflection } \\
-\quad \text { Modeling }\end{array}$ & $\begin{array}{l}\text { Teachers ask the group to present their work in } \\
\text { front of the class, } \\
\text { Teachers together all groups conclude problem } \\
\text { solving solutions in a worksheet } \\
\text { Teachers require all students to independently } \\
\text { make a summary of the material that has been } \\
\text { studied, presenting findings relating to other } \\
\text { sciences }\end{array}$ & $\begin{array}{l}\text { The group presented work and } \\
\text { other groups responding to the } \\
\text { work of the group that presented } \\
\text { All groups together teachers } \\
\text { discuss and conclude worksheet } \\
\text { solutions } \\
\text { Dare to convey findings } \\
\text { All students independently make } \\
\text { a summary, }\end{array}$ \\
\hline $\begin{array}{l}\text { Stage VII } \\
\text { Authentic Assessment }\end{array}$ & $\begin{array}{l}\text { The teacher asks all students to independently work } \\
\text { on the problems }\end{array}$ & $\begin{array}{l}\text { All students are independently working } \\
\text { on it. }\end{array}$ \\
\hline
\end{tabular}

\footnotetext{
Reference: Researcher modification.
} 


\subsection{Data Analysis}

The result data from this study was processed using steps as follows:

1) Pre-requisite Test

a) Data Normality Test

b) Homogeneity Test

The statistics used to test the similiarity of variance are F-test:

$$
\begin{gathered}
\mathrm{F}=\frac{\text { bigger variance }}{\text { lesser variance }} \\
\mathrm{F}=\frac{s_{1}^{2}}{s_{2}^{2}}
\end{gathered}
$$

(Susetyo, 2010).

Based on the normality test and the homogeneity test, it is concluded that researchers are eligible to conduct research on experimental classes and control classes.

2) Hypothesis Test

Before testing the hypothesis, the T-test for normality and homogeneity of the post-test data obtained by the compilation evaluates at the end of the study. Statistical analysis that has been used are T-test (two difference test average).

$$
\begin{gathered}
\mathrm{H}_{0:} \mu_{E}-\mu_{k}<0 \\
\mathrm{H}_{1:} \mu_{E}-\mu_{k}>0 \\
\mathrm{t}=\frac{\overline{x_{1}}-\overline{x_{2}}}{s \sqrt{\frac{1}{n_{1}}+\frac{1}{n_{2}}}}
\end{gathered}
$$

with sample variance:

$$
\mathrm{S}^{2}=\frac{\left(n_{1}-1\right) S_{1}^{1}+\left(n_{2}-1\right) S_{2}^{2}}{n_{1}+n_{2}-2}
$$

(Susetyo 2010)

Description:

$\mu_{\mathrm{E}}$ : means of student learning outcome that using CTI approach

$\mu_{\mathrm{k}}$ : means of student learning outcome that using Conventional approach

$\overline{x_{1}}$ : mean value of experiment class learning outcome

$\overline{x_{2}}$ : mean value of control class learning outcome

$\mathrm{S}^{2}$ : combined variant

$S_{1}^{2}$ : experiment class variant

$S_{2}^{2}$ : control class variant

$n_{1}$ : the amount of experiment class student

$n_{2}$ : the amount of control class student

As the criteria of hypothesis test: ignored $\mathrm{H}_{0}$ if $\mathrm{t}_{\text {count }}>\mathrm{t}_{\text {tabel }}$ with $\alpha=5 \%$

\section{Result and Discussion}

\subsection{Research Data Description}

Based on the results of the research taken from two classes, namely experimentation class and control class of junior high students, data obtained from the test results of students before and after obtaining treatment. The range of pre-tests and post-test values is 5-100. This data is further analysed and the results of processing are presented as follows, averaging the results of the pre-test in the experimental class 23 and control class 15 with a minimum score of experiment class 10 and control class 5 , and there is an increase on the average learning results of post-test 
in the experimental class to be 84 while in the control class 71 with a minimum score of experimentation class 70 and control class 60 . Before testing the hypothesis using the $t$ test, homogeneity and normality tests are conducted first, and the data used are post-test data from both classes.

\subsection{Pre-Requisite Test}

a) Normality Test used Lillyfors Test

The result of normality post test score for experiment class show $\mathrm{L}_{\text {count }}=0.1629$. Because $\mathrm{L}_{\text {count }}=0.1629<\mathrm{L}_{\text {table }}=$ 0.173 , so the post-test score for experiment class are normally distributed. The normality post-test score for control class show $\mathrm{L}_{\text {count }}$ value $=0.1492$. Because of $\mathrm{L}_{\text {count }}=0.1492<\mathrm{L}_{\text {table }}=0.173$ so the post-test score for control class distributed normally.

b) Homogeneity Varians Test

A homogeneity variance test was carried out with the analysis of the similarity testing of the two variances using F-test statistics on post-test data. The result is $S_{1}^{2}=132.25$ and $S_{2}^{2}=94.33$ give value $\mathrm{F}_{\text {count }}=1.40$ whether $\mathrm{F}$ table $=1.98$. This things shows that $\mathrm{F}_{\text {hitung }}<\mathrm{F}_{\text {table }}$ or $\mathrm{F}=1.40<F_{\alpha\left(d b_{1}, d b_{2}\right)}=1.98$ then accept $H_{0}: \sigma_{1}^{2}=\sigma_{2}^{2}$. So, the variances from both classes are homogenous.

\subsection{Hypothesis Test}

Hypothesis testing is done by using the test of the difference of two averages with $t$ test statistics and obtained $t_{\text {count }}$ $=4.38>\mathrm{t}_{\text {table }}=2.01$ which mean ignore $\mathrm{H}_{0}$ and accept $\mathrm{H}_{1}$. These things mean that implementing CTI learning approach will improve and increase learning outcomes in statistical matter of centralization (mean, mode, and median).

\subsection{Discussion}

Based on the results of the study conducted on students of class IX, shows there is a difference between the learning outcomes achieved by the students after treatment, i.e. in experimental classes using the CTL approach and the control class using conventional learning, where the average student learning outcomes in the experiment class is higher than the student learning outcomes of the control class. This is indicated by the average test results given in both classes, for the experimental class the pre-test score was 23 and for the post-test score was 84 while for the control class the pre-test score was 15 and for the post-test score was 71, with thus learning using the Contextual Teaching and Learning approach can be applied to the learning of statistical material in the size of concentration (mean, mode, and median).

\section{Conclusion}

It concluded that the student learning outcomes with CTL approach is better than the learning outcomes of students taught by conventional learning process especially on learning of statistical material (mean, mode, and median) in grade IX Junior School.

\section{References}

Fathur, R. (2007). Strategi Belajar Mengajar. Bandung: PT. Refika Aditama.

Johnson, B. E. (2011). Contextual Teaching and Learning. Bandung: Kaifa.

Kurniati, K., Kusumah, Y. S., Sabandar, J., \& Herman, T. (2015). Mathematical critical thinking ability through contextual teaching and learning approach. Journal on Mathematics Education, 6(1), 53-62. https://doi.org/10.22342/jme.6.1.1901.53-62

Mardianto, \& Wijaya, E. L. (2016). The Effect of Contextual Teaching and Learning (CTL) and Conventional Method on Mathematics Thinking Ability of Islamic Senior High School Student 1 in Medan. Journal of Arts, Science \& Commerce, 7(4), 100-107.

Mauliana, Ikhsan, M., \& Subianto, M. (2018). Development of Learning Tool with Contextual Teaching and Learning (CTL) Approach to Improve Student Mathematical Connection Ability. Journal of Physics: Conf. Series (Vol. 1088). https://doi.org/10.1088/1742-6596/1088/1/012012

Pattimukay. (2009). Model Pembelajaran Konvensional.

Rochsun. (2008). Peningkatan Hasil Belajar Statistika Melalui Pendekatan Berbasis Kontekstual. Retrieved from http://www.rochsun.com/2008/peningkatan-hasil-belajar-statistika-melalui-pendekatan-berbasiskontekstual/

Ruseffendi. (1993). Pendidikan Matematika 3. Jakarta : Depdikbud. 
Sudjana, N. (2003). Penilaian Hasil Proses Belajar Mengajar. Bandung: PT. Remaja Rosdakarya.

Sugiyono. (2010). Metode Penelitian Pendidikan (pendekatan kuantitatif, kualitatif dan R\&D). Bandung: Alfabeta.

Suherman. (2003). Belajar dan Pembelajaran. Bandung: Alfabeta.

Suriasumantri, J. (2010). Menguak Cakrawala Keilmuan, Landasan Filosofis Penulisan Tesis dan Disertasi. Jakarta: Jakarta State University.

Susetyo. (2010). Statistika untuk Analisis Data Penelitian. Bandung: PT. Refika Aditama.

\section{Copyrights}

Copyright for this article is retained by the author(s), with first publication rights granted to the journal.

This is an open-access article distributed under the terms and conditions of the Creative Commons Attribution license (http://creativecommons.org/licenses/by/4.0/). 